\title{
The development and validation of an ergonomics index for assessing tractor operator work place
}

\author{
Juan Paulo Barbieri ${ }^{1}$ José Fernando Schlosser ${ }^{2}$ Marcelo Silveira de Farias $^{3}$ \\ Giácomo Müller Negri $^{2^{*}}$ Luis Fernando Vargas de Oliveira ${ }^{4}$
}

\begin{abstract}
'Programa de Pós-graduação em Engenharia Agrícola (PPGEA), Universidade Federal de Santa Maria (UFSM), 97105-900, Santa Maria, RS, Brasil. E-mail: barbieri.juan@hotmail.com. "Corresponding author.

${ }^{2}$ Departamento de Engenharia Rural (DER), Centro de Ciências Rurais (CCR), Universidade Federal de Santa Maria (UFSM), Santa Maria, RS, Brasil.

${ }^{3}$ Departamento de Ciências Agronômicas e Ambientais (DCAA), Universidade Federal de Santa Maria (UFSM), Campus Frederico Westphalen, Frederico Westphalen, RS, Brasil.

${ }^{4}$ Departamento de Engenharia Mecânica (DEM), Centro de Tecnologia (CT), Universidade Federal de Santa Maria (UFSM), Santa Maria, RS, Brasil.

ABSTRACT: This study aimed to develop and validate an ergonomics index for the operator workplace assessment of agricultural tractors sold in the Brazilian market. To develop the ergonomics index, the operator work places were assessed for compliance with current, national and international, safety and ergonomics standards. The following standards were analyzed to develop ergonomics index: ISO 15077 (1996), which regulates the position of operator controls; ABNT NBR ISO 4254-1(2015) and ABNT NBR ISO 4252 (2011), which regulate the access to operator workplaces; and NR 12 (2010), which determines the mandatory items of operator workplaces.Thirty-four operator work places of 152 models of new agricultural tractors sold in the Brazilian market were analyzed in this study. Ergonomics index was developed and validated using these standards, and the findings enabled the ranking of agricultural tractors. Therefore, the proposed ergonomics index proved feasible and may be applied to other agricultural machines.

Key words: ergonomics, safety, operator controls, access, standards.
\end{abstract}

\section{Criação e validação de índice ergonômico para avaliação}

de postos de operação de tratores agrícolas

RESUMO: Objetivou-se com este trabalho criar e validar um índice ergonômico capaz de qualificar os postos de operação de tratores agrícolas comercializados no mercado brasileiro. Para a composição do indice ergonômico, os postos de operação foram avaliados quanto ao atendimento às normas vigentes, nacionais e internacionais, de segurança e de ergonomia. As seguintes normas foram levadas em consideração para a criação do indice ergonômico: ISO 15077 (1996) - determina o posicionamento dos órgãos de comando; ABNT NBR ISO 4254-1 (2015) e ABNT NBR ISO 4252 (2011) - referem-se à acessibilidade aos postos de operação; e NR 12 (2010) - determina a presença de itens obrigatórios nos postos de operação. Fizeram parte desta análise 34 postos de operação, que são montados em 152 modelos de tratores agrícolas novos, comercializados no mercado brasileiro. Com o auxílio dessas normas o índice ergonômico foi desenvolvido e validado usando esses padrões, e os resultados permitiram ranquear os tratores agrícolas. Conclui-se que o indice ergonômico proposto se mostrou eficiente quanto à exequibilidade e pode ser aplicado em outras máquinas agrícolas.

Palavras-chave: ergonomia, segurança, comandos de operação, acessibilidade, normativas.

\section{INTRODUCTION}

In modern agriculture, the agricultural tractor is crucial for various farming activities. According to ROZIN (2004), the tractor has been regarded as the driving force for the Brazilian agricultural development owing to its versatility in performing numerous tasks in rural environments and isthe source of power and traction for several agricultural machines and implements.

Ergonomics approach tends to develop operator work places that reduce the biomechanical and cognitive constraints and help the operators to maintain an adequate work posture (IIDA, 2005). SCHLOSSER et al. (2002a) stress the importance of operators reaching and activating operator controls with minimum effort, and maintaining appropriate body posture.

An ergonomic operator work place design must ensure adequate work station space for any operator, regardless of his or her physical structure, to adopt comfortable work postures and for personal belongings (FERNANDES et al., 2010). Agricultural modernization has led to significant improvement 
in the operator work places of Brazilian tractors by encouraging the application of ergonomic methods (FRANCHINI, 2007); however, many requirements remain unfulfilled (NIETIEDT et al., 2012).

The position and characteristics of tractor access platforms may cause numerous accidents, especially in the absence of properly designed hand holds and handrails for tractor mounting and dismounting (SCHLOSSER et al., 2002b). Access platforms having adequate size, space, and safety can contribute to decreasing risk exposure, thereby decreasing the number of work accidents (MATTAR et al., 2010).

With the objective of evaluating the safety and ergonomics levels of operator work places agricultural machinery, CASALI et al. (2011) assessed the position of the main controls of self-propelled sprayers. The authors concluded thatignitionswitches are commonly located with in the comfort zone of seated operators in sprayers with multifunctional controls.

To analyze the compliance with the standard regulating the position of hand and foot controls, ROZIN et al. (2010) assessed 35 tractor operator work places based on ABNT NBR ISO 4253 (1999) recommendations. The authors concluded that the clutch and accelerator pedals were the items that best and worst met the standard, respectively.

NIETIEDT et al. (2012) analyzed the position of operator controls in four new agricultural tractors with $55 \mathrm{~kW}(75 \mathrm{cv})$ nominal power, and concluded that frequently used controls were most commonly reported in the comfort zone of the Valtra tractor, model A750. DEBIASI et al. (2004) evaluated agricultural tractors used in the Central region of Rio Grande do Sul, and concluded that these tractors have several ergonomics and safety limitations.

Various indices have been developed by researchers to assess and classify agricultural tractors based on the safety and ergonomics characteristics of operator work places. In this regard, ROZIN (2004) proposed an index divided into three plots: the first referred to operator controls, the second referred to the access platformand the third considered the general characteristics of the operator work place.

In line with ROZIN (2004), this study aims to develop an Operator Work place Ergonomics Index (OWEI) to assess the compliance with operator work place standards of new agricultural tractors sold in the Brazilian market, to validate this index according to specifications recommended by safety and ergonomics standards and, finally, to rank operator work places based on the proposed index.

\section{MATERIALS AND METHODS}

The OWEI was developed considering the Brazilian and international safety and ergonomics standards, including the ABNT NBR ISO 4252 (2011) and NR 12 (2010) standards, and those previously used by ROZIN (2004), namely, the ISO 17077 (1996) and ABNT NBR ISO 4254-1 (2015) standards used for the Seat Index Point.

Each operator work place was scored as a function of compliance with the standards used. The scoring method was based on the Index Number (IN) theory and totaled one (01). The IN isa value that expresses an amount in comparison to a reference quantity, that is, relative values (ENDO, 1986). In this study, the baseline/reference was taken as 100. Thus, the behavior of the variables was analyzed (Table 1) regarding compliance with the standards.

The ISO 15077 (1996) standard regulates the position of operator controls and their location with in the comfort zones of seated operators. Of all controls that may be found in an operator work place, 22 were assessed in cab tractors and 21 in cables stractors (Table 2).

The points assessed were plotted in three Cartesian axes (x, y, z) to establish the Vertical Longitudinal (VLP) and Upper Horizontal (UHP) profiles of operator work places. In the OWEI development, the ISO 15077 (1996) standard received the maximum score, 0.45 , because this standard regulates ergonomics is sues and the position, access to, and handing of controls, whose poor position may cause physical and mental fatigue among agricultural machinery operators, in addition to occupational diseases caused by repetitive movements (ROZIN, 2010).

Regarding safety and access to operator work place, the ABNT NBR ISO 4254-1 (2015) standard received a score of 0.25 because this standard regulates access steps and their number and size, and the presence and number of hand holds in both sides of the tractor.

The ABNT NBR ISO 4252 (2011) standard was used to assess the operator work place. This standard regulates tractor mounting and dismounting and the internal space of operator work places. Number and location of emergency exits and the dimensions of the internal free space of operator work places of agricultural tractors were analyzed according to this standard. Full compliance with this standard received a maximum score of 0.20 in the OWEI index because this standard regulates safety items, and their correct scalingin designing agricultural tractors decreases the risk ofwork accidents. 
Table 1 - Contribution of each standard to the Operator Work place Ergonomics Index (OWEI) of agricultural tractors sold in the Brazilian marketin 2016.

\begin{tabular}{|c|c|}
\hline Operator work place ergonomics index (OWEI) & Score \\
\hline Compliance with the ISO 15077 (1996) standard & 0.45 \\
\hline 21 controls & 0.02 \\
\hline Compliance with the ABNT NBR ISO 4254-1 (2015) standard & 0.25 \\
\hline Distance between steps & 0.027 \\
\hline Height from the first step to the ground & 0.027 \\
\hline Depth & 0.027 \\
\hline Vertical distance to the threshold & 0.027 \\
\hline Clearance & 0.027 \\
\hline Vertical distance to the ground & 0.027 \\
\hline Minimum width & 0.027 \\
\hline Maximum width & 0.027 \\
\hline Vertical stops on both sides & 0.027 \\
\hline Non-skid surface & 0.027 \\
\hline Compliance with the ABNT NBR ISO 4252 (2011) standard & 0.20 \\
\hline Emergency exits & 0.025 \\
\hline Mounting clearance & 0.025 \\
\hline Longitudinal clearance at $750-\mathrm{mm}$ height & 0.025 \\
\hline Longitudinal clearance at $1000-\mathrm{mm}$ height & 0.025 \\
\hline Longitudinal clearance at $1250-\mathrm{mm}$ height & 0.025 \\
\hline Distance to the ceiling surface of the cab & 0.025 \\
\hline Lateral space & 0.025 \\
\hline Distance from the steering wheel to the cab surface & 0.025 \\
\hline Compliance with the NR 12 (2010) & 0.10 \\
\hline Ignition key or locking device & 0.006 \\
\hline Protection at the bottom of the steps & 0.006 \\
\hline Position Taillights & 0.006 \\
\hline Back-up beeper & 0.006 \\
\hline Rear view mirror & 0.006 \\
\hline Top protection structure - TPS & 0.006 \\
\hline Seat belt & 0.006 \\
\hline Manual available at the operator work place & 0.006 \\
\hline Safe, weather proof, and corrosion resistant & 0.006 \\
\hline Steering wheel is not considered a handhold & 0.006 \\
\hline Tires, hubs, wheels, and fenders considered steps & 0.006 \\
\hline Has handholds on both sides of the tractor & 0.006 \\
\hline Three-point mount and dismount & 0.006 \\
\hline Handle with a minimum length of $150 \mathrm{~mm}$ & 0.006 \\
\hline Slope of the ladder meets the standard requirements & 0.006 \\
\hline Preventing the accumulation of water and dirt & 0.006 \\
\hline Total & 1.00 \\
\hline
\end{tabular}

To assess the presence of mandatory safety items inoperator work places, NR 12 (2010), which defines technical references, fundamental principles, and protection measures that must be observed in the work environment, was applied setting the maximum score at 0.10 . NR 12 (2010) received a lower score than the other standards because several safety and ergonomics items regulated by this standard are included in the other standards used in this study. Compliance with the following items was analyzed: ignition switch, taillight, horn and access platform steps, and surface.

To validate the OWEI, 34 operator work places of 152 new agricultural tractor models sold 
Table 2 - Nomenclature used to classify the operator work places of agricultural tractors sampled in the main dealers of the Central region of Rio Grande do Sul in 2016.

\begin{tabular}{|c|c|c|c|}
\hline \multirow{5}{*}{ Agrale } & 500 & $1 \mathrm{AA}$ & Cabless \\
\hline & \multirow{2}{*}{5000} & $2 \mathrm{AP}$ & Cabless \\
\hline & & $2 \mathrm{AC}$ & $\mathrm{Cab}$ \\
\hline & \multirow{2}{*}{6000} & $3 \mathrm{AP}$ & Cabless \\
\hline & & $3 \mathrm{AC}$ & $\mathrm{Cab}$ \\
\hline \multirow{5}{*}{ Case-IH } & \multirow{3}{*}{ FARMAL } & $1 \mathrm{CP}$ & Cabless \\
\hline & & $1 \mathrm{CC}$ & $\mathrm{Cab}$ \\
\hline & & $2 \mathrm{CP}$ & Cabless \\
\hline & PUMA & $3 \mathrm{CC}$ & $\mathrm{Cab}$ \\
\hline & MAGNUM & $4 \mathrm{CC}$ & $\mathrm{Cab}$ \\
\hline \multirow{5}{*}{ John Deere } & \multirow{3}{*}{$5 \mathrm{E}$} & $2 \mathrm{JC}$ & $\mathrm{Cab}$ \\
\hline & & 2JP & Cabless \\
\hline & & $1 \mathrm{JS}$ & Cabless \\
\hline & $6 \mathrm{~J}$ & $3 \mathrm{JC}$ & $\mathrm{Cab}$ \\
\hline & $7 \mathrm{~J}$ & $4 \mathrm{JC}$ & $\mathrm{Cab}$ \\
\hline \multirow{4}{*}{ LS Tractor } & \multirow{2}{*}{ PLUS } & $1 \mathrm{LP}$ & $\mathrm{Cab}$ \\
\hline & & $1 \mathrm{LC}$ & Cabless \\
\hline & \multirow{2}{*}{$\mathrm{U}$} & $2 \mathrm{LP}$ & Cabless \\
\hline & & $2 \mathrm{LC}$ & $\mathrm{Cab}$ \\
\hline \multirow{6}{*}{ Massey Ferguson } & \multirow{2}{*}{4200} & $1 \mathrm{MP}$ & Cabless \\
\hline & & $1 \mathrm{MC}$ & $\mathrm{Cab}$ \\
\hline & \multirow{2}{*}{7100} & $3 \mathrm{MP}$ & Cabless \\
\hline & & $3 \mathrm{MC}$ & $\mathrm{Cab}$ \\
\hline & 7000 & $4 \mathrm{MC}$ & $\mathrm{Cab}$ \\
\hline & 6000 & $2 \mathrm{MC}$ & $\mathrm{Cab}$ \\
\hline \multirow{5}{*}{ New Holland } & \multirow{2}{*}{$\mathrm{TL}$} & $1 \mathrm{NP}$ & Cabless \\
\hline & & $1 \mathrm{NC}$ & $\mathrm{Cab}$ \\
\hline & SÉRIE 30 & $2 \mathrm{NA}$ & Cabless \\
\hline & T6 & $3 \mathrm{NC}$ & $\mathrm{Cab}$ \\
\hline & $\mathrm{T} 7$ & $4 \mathrm{NC}$ & $\mathrm{Cab}$ \\
\hline \multirow{4}{*}{ Valtra } & A & $1 \mathrm{VP}$ & Cabless \\
\hline & $\mathrm{BM}$ & $2 \mathrm{VC}$ & $\mathrm{Cab}$ \\
\hline & $\mathrm{BH}$ & $3 \mathrm{VC}$ & $\mathrm{Cab}$ \\
\hline & BT & $4 \mathrm{VC}$ & $\mathrm{Cab}$ \\
\hline
\end{tabular}

in the Brazilian market were assessed. Data were collected through ergonomics assessments performed at the main agricultural machinery concessionaires of the Central Depression region of Rio Grande do Sul. An agricultural tractor must meet all safety and ergonomics standards imposed by the current legislation in force to receive the maximum score $(\mathrm{OWEI}=1.00)$.

The sample consisted of tractors with $4 \times 2$ and $4 \times 2$ wheels, auxiliary front wheel drive (FWD), $36.7 \mathrm{~kW}(50 \mathrm{cv})$ nominal power, rear axle track higher than $1280 \mathrm{~mm}$, and $600 \mathrm{~kg}$ minimum mass. Tractors were grouped using the classification proposed by FARIAS et al. (2016). This grouping also considered homogeneous operator work places, and identified the work places according to the following parameters: operator work place type (conventional, with a semi-platform, or with an access platform), and version (cab and cabless).

The nomenclature of operator work places consists of three alphanumeric characters. The first character is an integer corresponding to the commercial line or serial number of the tractor, the second one corresponds to the first letter of the brand of the tractor, and the thirdone refers to the type of operator work place, where in cabless operator work places, operator work places with a semi-platform, cabless operator work places with an access platform, and cab operator work places are labeled A, S, P, and C, respectively (Table 2). 
Operator work places of agricultural tractors of the main companies operating in the Brazilian market, found in dealers of the Central region of Rio Grande do Sul and sold in 2016, were sampled. They were identified by the following brand names: Agrale, Case-IH, John Deere, LS Tractor, Massey Ferguson, New Holland, and Valtra. The ergonomics and safety characteristics of agricultural tractors established as standard by the manufacturer were analyzed.

\section{RESULTS AND DISCUSSION}

Regarding the compliance with the ISO 15077 (1996) standard, the operator work place with the highest number of controls located in comfort zones advocated by the standard was $4 \mathrm{CC}$, scoring 0.332 , and the work place with the lowest score was 2NA, scoring 0.156 for a total score of 0.45 .

The operator work places 1AA, 2AP, 2AC, 3AP, and 3AC lacked steps with nonslip characteristics, failing to meet the ABNT NBR ISO 4254-1 (2015) standard, and scored zero. Conversely, in $84.84 \%$ operator work places, the steps havea nonslip surface but lack side stops at least in one of the access steps, failing to meet the standard recommendation and received a score of 0.013 .

Regarding the height from the first step to the ground, used to mount and dismount the tractor, 95.24\% cabless tractors assessed met the ABNT NBR ISO 4254-1 (2015) standard, whereas the operator work places of cab tractors showed $100 \%$ compliance and received the highest score $(0.027)$. This result is in contrast with MATTAR et al. (2010), who reported that the height from the first step to the ground of $70.43 \%$ tractors assessed was lower than or equal to that specified by the standard.

The analysis of step depth compliance with the ABNT NBR ISO 4254-1 (2015) standard showed that operator work places of cabless tractors had only $45.24 \%$ compliance and those of cab tractors had $77.78 \%$ compliance. MATTAR et al. (2010) assessed tractor step length, and concluded that $61.90 \%$ tractors met the standard requirements; this value is similar to that reported in the present study (61.51\%).

Regarding the vertical distance from the last step to the cab thres hold, all tractors with a multi-step frame met the ABNT NBR ISO 4254-1 (2015) standard, receiving the maximum score in this item, and the analysis of tractor step width showed that the number of operator work places of cabless tractors was higher than that of cab tractors $(22.22 \%)$. Only 14 of the 34 operator work places received the maximum score $(0.25)$ regarding the compliance with the ABNT NBR ISO 4254-1 (2015) standard.

The analysis of the number of emergency exits based on the ABNT NBR ISO 4252 (2011) standard, which requires at least two, showed that all cab tractors showed $100 \%$ compliance, receiving the maximum score of 0.025 . In all cases, the exits were found at the left door and the rear window of the cab. However, regarding the distance from the seat to the ceiling of the cab, six operator work places $(2 \mathrm{AC}$, $1 \mathrm{MC}, 3 \mathrm{MP}, 1 \mathrm{LC}, 3 \mathrm{JC}$, and 4JC) scored zero. Another item assessed, which was not met in three operator work places (4MC, $2 \mathrm{VC}$, and $4 \mathrm{VC}$ ), was the distance from the steering wheel to the cab surface. This may be explained by the control positioned next to the steering wheel.

The analysis of cabin door size showed that all 34 operator work places comply with the standards, when assessing the longitudinal clearance at the largest width and the entry clearance measurements recommended by the ABNT NBR ISO 4252 (2011) standard possibly because the tractor door is considered as an emergency exit in case of accidents.

Analyzing the slope of the steps according to the NR 12 (2010) standard, the tractor steps are not visible to the operator when dismountingin $57.78 \%$ operator work places. According to ROZIN (2004), the lack of visibility of tractor steps maylead operators to jump, increasing the like lihood of an accident. In a research study conducted among operators of the Central region of the state of Rio Grande do Sul, DEBIASI et al. (2004) consider the dismounting structure of some operator work places of agricultural tractors inadequate and unsafe.

Regarding the presence of mandatory items, seven operator work places (3CC, 4CC, $3 \mathrm{JC}, 4 \mathrm{JC}, 2 \mathrm{MC}, 4 \mathrm{MC}$, and $4 \mathrm{VC}$ ), met $100 \%$ safety recommendations established by the NR 12 (2010) standard and received the maximum score $(0.1)$. The $3 \mathrm{AP}$ operator work place had the lowest compliance and scored 0.081 .

Table 3 outlines the operator work places assessed and ranked in decreasing order, that is, from the highest to lowest OWEI, considering the compliance with the items assessedin relation to the standards. As outlined in table 3, the 4CC operator work place, Case-IH brand, had the highest ergonomics index of all operator work places analyzed (0.8912). The lowest OWEI was reported in the 2NA operator work place, New Holland brand (0.7173). The mean OWE Iwas 0.8026 , and $48.48 \%$ operator work places ranked higher than the mean OWEI. 
Table 3 - Operator Workplace Ergonomics Index (OWEI) ranking of operator work $(\mathrm{OW})$ place of agricultural tractors assessed and sold in 2016.

\begin{tabular}{|c|c|c|c|}
\hline Ranking & OW & Manufacturer & OWEI \\
\hline 1 & $4 \mathrm{CC}$ & Case-IH & 0.8912 \\
\hline 2 & $2 \mathrm{MC}$ & Massey Ferguson & 0.8565 \\
\hline 2 & $3 \mathrm{VC}$ & Valtra & 0.8462 \\
\hline 2 & $3 \mathrm{CC}$ & Case-IH & 0.8416 \\
\hline 5 & $2 \mathrm{JC}$ & John Deere & 0.8404 \\
\hline 6 & $3 \mathrm{NC}$ & New Holland & 0.8404 \\
\hline 7 & $4 \mathrm{VC}$ & Valtra & 0.8354 \\
\hline 8 & $4 \mathrm{MC}$ & Massey Ferguson & 0.8354 \\
\hline 9 & $1 \mathrm{MC}$ & Massey Ferguson & 0.8341 \\
\hline 10 & $3 \mathrm{MP}$ & Massey Ferguson & 0.8330 \\
\hline 11 & $4 \mathrm{NC}$ & New Holland & 0.8246 \\
\hline 12 & $1 \mathrm{NP}$ & New Holland & 0.8200 \\
\hline 13 & $1 \mathrm{NC}$ & New Holland & 0.8143 \\
\hline 14 & $1 \mathrm{AP}$ & Agrale & 0.8141 \\
\hline 15 & $1 \mathrm{CC}$ & Case-IH & 0.8128 \\
\hline 16 & $3 \mathrm{JC}$ & John Deere & 0.8067 \\
\hline 17 & $2 \mathrm{LP}$ & LS Tractor & 0.8057 \\
\hline 18 & $4 \mathrm{JC}$ & John Deere & 0.8023 \\
\hline 19 & $1 \mathrm{MP}$ & Massey Ferguson & 0.8012 \\
\hline 20 & $1 \mathrm{CP}$ & Case-IH & 0.8010 \\
\hline 21 & $1 \mathrm{JP}$ & John Deere & 0.7895 \\
\hline 22 & $2 \mathrm{CP}$ & Case-IH & 0.7882 \\
\hline 23 & $3 \mathrm{AC}$ & Agrale & 0.7825 \\
\hline 24 & $2 J P$ & John Deere & 0.7809 \\
\hline 25 & $2 \mathrm{LC}$ & LS Tractor & 0.7796 \\
\hline 26 & $2 \mathrm{AC}$ & Agrale & 0.7775 \\
\hline 27 & $2 \mathrm{VC}$ & Valtra & 0.7775 \\
\hline 28 & $1 \mathrm{LC}$ & LS Tractor & 0.7739 \\
\hline 29 & $1 \mathrm{VP}$ & Valtra & 0.7693 \\
\hline 30 & $3 \mathrm{AP}$ & Agrale & 0.7564 \\
\hline 31 & $1 \mathrm{LP}$ & LS Tractor & 0.7546 \\
\hline 32 & $3 \mathrm{MC}$ & Massey Ferguson & 0.7516 \\
\hline 33 & $2 \mathrm{AP}$ & Agrale & 0.7443 \\
\hline 34 & $2 \mathrm{NA}$ & New Holland & 0.7173 \\
\hline \multicolumn{3}{|c|}{ Coefficient of Variation (\%) } & 4.53 \\
\hline
\end{tabular}

Because the safety and ergonomics standards of agricultural tractors assessed in this study are in force in Brazil, manufacturers should fully comply with these standards, which would mean a 1.0 OWEI. However, the findings suggested that all tractors fail to comply with Brazilian and international standards.

\section{CONCLUSION}

This study proposed an ergonomics index for the operator work place assessment of agricultural tractors sold in the Brazilian market. The proposed ergonomics index (OWEI) proved feasible and improved the assessment of safety and ergonomics characteristics of operator work places of agricultural tractors.

Based on the proposed score, tractors were ranked using the OWEI. However, no tractor fully met the safety and ergonomics standards.

\section{ACKNOWLEDGEMENTS}

The authors thank the Conselho Nacional de Desenvolvimento Científico e Tecnológico $(\mathrm{CNPq})$ for funding the study by awarding a graduate scholarshipanda research grant to the second author

\section{REFERENCES}

ABNT. (ASSOCIAÇÃO BRASILEIRA DE NORMAS TÉCNICAS). ABNT NBR ISO 4252: tratores agrícolas: local de trabalho do operador, acesso e saída: dimensões. Rio de Janeiro, 2011. 6p.

ABNT. (ASSOCIAÇÃO BRASILEIRA DE NORMAS TÉCNICAS). ABNT NBR ISO 4254-1: máquinas agrícolas segurança parte 1: requisitos gerais. Rio de Janeiro, 2015. 48p.

BRASIL. Ministério do Trabalho e Emprego. Norma Regulamentadora $\mathbf{N}^{\mathbf{0}}$ 12. 2010.Available from: <http://portal. mte.gov.br/data/files/8A7C816A4295EFDF0142FC261E820E2C/ NR-12\%20(atualizada \%202013)\%20III\%20-\%20(sem\%2030\%20 meses).pdf>. Accessed: Mar. 29, 2017.

CASALI, A.L. et al. Conformance of operating post of selfpropelled sprayers.Engenharia na Agricultura, Viçosa, v.19, n.6, p.548-556, 2011.Availablefrom: $<$ http://dx.doi.org/10.13083/14143984.v19n06a07>. Accessed: Feb.17, 2017.doi: 10.13083/14143984.v19n06a07.

DEBIASI, H. et al. Ergonomic characteristics of agricultural tractors used in central region of Rio Grande do Sul State, Brazil. Ciência Rural, Santa Maria, v.34, n.6, p.1807-1811, 2004.Availablefrom: $<$ http://www.scielo.br/scielo.php?script=sci arttext\&pid=S0103$84782004000600021 \& \operatorname{lng}=$ en\&nrm=iso\&tlng=pt $>$. Accessed: Feb. 16, 2017. doi: 10.1590/S0103-84782004000600021.

ENDO, S.K. Números índices. 1.ed. São Paulo: Atual, 1986. 74p.

FARIAS, M.S. et al.Evaluation of new agricultural tractors engines by using a portable dynamometer. Ciência Rural, Santa Maria, v.46, n.5, p.820-824, 2016. Available from: <http://www.scielo.br/ scielo.php?script=sci arttext\&pid=S0103-84782016000500820>. Accessed: Feb. 16, 2017. doi: 10.1590/0103-8478cr20150406.

FERNANDES, H.C. et al. Ergonomic evaluation of the operator cabin of a forest tractor. Revista Ceres, Viçosa, v.57, n.3, p.307-314, 2010.Available from: $<$ http://www.scielo.br/scielo.php? script=sci arttext\&pid=S0034-737X2010000300004>. Accessed: Feb. 12, 2017. doi: 10.1590/S0034-737X2010000300004.

FRANCHINI, D. Análise do nível de vibrações verticais no assento de um trator agrícola. 2007. 139p. Dissertação (Mestrado em Engenharia Agrícola) - Universidade Federal de Santa Maria, Santa Maria, 2007. 
IIDA, I. Ergonomia: projeto e produção.2. ed. São Paulo: Ed. Edgard Blücher, 2005. 465p.

ISO. (INTERNATIONAL ORGANIZATION FOR STANDARDIZATION). ISO 15077: tractors and machinery for agriculture and forestry: operator controls: actuating forces, their displacement and location. Genève, 1996. 14p.

MATTAR, D.P et. al. Conformity of the accesses and exits of agricultural tractors workplaces accordingto NBR/ISO 4252 standard. EngenhariaAgrícola, Jaboticabal, v.30, n. 1, p.74-81, 2010.Available from: $<$ http://www.scielo.br/scielo.php?script=sci arttext\&pid $=\mathrm{S} 0100-69162010000100008 \& \operatorname{lng}=\mathrm{en} \& \mathrm{nrm}=$ is o\&tlng=pt $>$. Accessed: Feb. 12, 2017. doi: 10.1590/S010069162010000100008 .

NIETIEDT G.H.et al. Distribution of operation controls in national agricultural tractors with $55 \mathrm{~kW}$ of power.Revista Brasileira de EngenhariaAgrícola e Ambiental, Campina Grande, v.16, n.6, p.690-695, 2012. Available from: <http://www.scielo.br/pdf/rbeaa/ v16n6/v16n06a15.pdf $>$. Accessed: Feb. 20, 2017. doi: 10.1590/ S1415-43662012000600015.
ROZIN, D. Conformidade do posto de operação de tratores agrícolas nacionais com normas de ergonomia e segurança. 2004, 187p. Dissertação (Mestrado em Engenharia Agrícola) Universidade Federal de Santa Maria, Santa Maria, 2004.

ROZIN, D. et al. Compliance of the command operations of national agricultural tractors with the NBR ISO 4253 standard. RevistaBrasileira de EngenhariaAgrícola e Ambiental, Campina Grande, v.14, p.1014-1019, 2010.Available from: <http:// dx.doi.org/10.1590/S1415-43662010000900015>. Accessed: Feb. 16, 2017. doi: 10.1590/S1415-43662010000900015.

SCHLOSSER, J.F et al. Characterization of the accidents involving agricultural tractors. Ciência Rural, Santa Maria, v.32, n.06, p.4552, 2002 (a). Availablefrom: <http://dx.doi.org/10.1590/S010384782002000600010>. Accessed: Feb. 16, 2017. doi: 10.1590 S0103-84782002000600010.

SCHLOSSER, J.F. et al. Anthropometrics applied to the agricultural tractors operators. Ciência Rural, Santa Maria, v.32, n.06, p.61-72, 2002 (b) Availablefrom: <http://dx.doi.org/10.1590/S0103-84782002000600011>. Accessed: Feb. 15, 2017. doi: 10.1590/S0103-84782002000600010. 